\title{
Clinically Important Depressive Symptoms among Health Careers Students in CartagenaColombia
}

\author{
Zuleima Cogollo Milanés ${ }^{1}$, Edna Gómez Bustamante ${ }^{1}$, \\ Muna Hamdan Rodríguez ${ }^{1}$ \\ 1. Collective Health Care Group, Faculty of Nursing, Universidad de Cartagena, Colombia
}

\begin{abstract}
Background: Some studies show a high prevalence of clinically significant depressive symptoms $(C S D S)$ in college students. However, few researches compare the prevalence of these symptoms among health careers' students.Objective: To determine the prevalence and demographic factors associated with CSDS among health careers' students in Cartagena, Colombia. Methods: A cross-sectional study was designed. Students of nursing, medicine, dentistry, chemical and pharmaceutical chemistry participated in this survey. The CSDS during the last fifteen days were quantified with the abbreviated Zung Self-Rating Depression Scale (cutoff point 22/40). Logistic regression was used to control demographic variables associated with CSDS.Results: A total of 405 students accepted to participate. The mean age was 20.0 years $(S D=2.1)$. The CSDS prevalence was 48.1\%. The presence of CSDS was associated with studying nursing, dentistry or pharmaceutical chemistry compared with medicine or chemistry (OR=1.9, 95\%CI 1.3-2.9) and students younger than 20 years compared to those older than 20 years $(O R=1.6,95 \% C I$ 1.1-2.4). Conclusions: The prevalence of CSDS in health careers'students is high, and it is associated with the studied career and fewer years of age. More studies are needed in this area.
\end{abstract}

Keywords:Prevalence; Depressive symptoms; Students; Academics; Cross-sectional study.

\section{Introduction}

It is defined as clinically significant depressive symptoms (CSDS), those which are identified using instruments that provide us with diagnostic accuracy, such as scales. These symptoms may be relevant enough to be included in any of the diagnostic categories specified in the classification of mental disorders best known in Latin American countries, such as: Major Depressive Disorder, Persistent Depressive Disorder (Dysthymia) and Unspecified Depressive Disorder(Minor Depressive Disorder, Recurrent Brief Depressive Disorder and Premenstrual Dysphoric Disorder) [1].

A systemic review by Ibrahim et al. to explore the prevalence of depression in university students of different races, reported that the prevalence of depression range was between $10 \%$ and $85 \%$, with an average of $30.6 \%$. This review suggested that university students experience depression at much higher levels than the general population [2].

Shamsuddin et al. in a study of correlation between anxiety, depression and stress among university students in Malaysia, found that the prevalence of anxiety surpassed the prevalence of stress and depression. However, the prevalence of depression was also high, $27.5 \%$ of students had moderate depression and $9.7 \%$ had severe or extremely severe depression [3].

Another study with Nigerian university students conducted by Aniebue et al.showed that the prevalence of depression among these was $23.3 \%$ [4]. Pereyra et al. found that the prevalence of depressive symptoms was $31.2 \%$ in health sciences students and $33.6 \%$ in medical students particularly at a private university in Lima [5].

Different studies show that the prevalence of CSDS is high in Colombian university students. Diaz N. reported that the prevalence of CSDS, measured with Zung Self- Rating Depression Scale reached $86.4 \%$ in students of different careers [6]. Amezquita et al.found a frequency of $49.8 \%$, quantified with the Beck Depression Inventory in nursing, biology and chemistry, social work, law, family development and other careers students[7]. Campo-Arias et al. documented a prevalence of $43.6 \%$, in students finishingunrelated to health careers, measured with the Zung Self - Rating Depression Scale[8]. Arrieta et al. found a prevalence of $56.6 \%$ for depression, anxiety and stress in dentistry students, in a university in Cartagena, measured by DASS 21 Self - Rating Scale [9].

The CSDS are associated with some demographic variables such as age, sex, social strata, origin and coexistence [5,9]. Guavita and Sanabria found a higher prevalence of CSDS in university students between the ages of 18 and 20 and women in Bogotá [10]. Whereas Miranda et al. found an inverse association between socioeconomic status and the presence of CSDS in women in Cali [11].

During the profesional training, the harmonious development of students skills, abilities, values and attitudes, aimed at the intellectual, personal and social self-sufficiency is at a high risk and may be affected by 
the presence of CSDS [12]. It is necessary to implement strategies for early identification of CSDS in this population, related to desertion, poor academic performance and even the appearance of certain complications, such as substance abuse $[9,13,14]$.

It is important that faculty, as health professionals,especially nursesget involved in educational programs, which highlight the importance of depression, the identification of depressive symptoms and coping with stress, in order to the students perform optimally.

The aim of this study was to determine the prevalence and certain demographic variables associated with CSDS in health careers students in Cartagena, Colombia.

\section{Methodology}

A cross-sectional study was designed,for which the principles for research with human beings contained in the Colombian regulations were followed and was subsequently approved by the institutional ethics committee[15]. The participation of students in the health área of a public university in Cartagena was requested. 1,578 students were enrolled in the university to that date. Students in the first and last semesters were systematically excluded. A stratified sample by faculty and semester was taken. A sample of 406 students for an expected prevalence of $40 \%$ of CSDS and an alpha error of 5\% was estimated. The participants filled individually, anonymously and confidentially the informed consent and a questionnaire including sociodemographic variables and the abbreviated Zung Self- Rating Depression Scale [16]. A research assistant oriented the participants on how to fill out the questionnaire and was willing to resolve doubts individually, and avoided the induce of responses.

The Zung Self - Rating Depression Scale is formed of 10 points with ordinal response pattern (from never to always). It gives scores between 20 and 40 and those considered CSDS scores are equal to or above 22 points. This scale was validated in Colombian university students [16]. However, in order to know the psychometric behavior in the sample selected, Cronbach's alpha coefficient was calculated.

Data were analyzed in the STATA 9.0 program. A descriptive bivariate and multivariate analysis was performed. Percentages, averages, standard deviation (SD) and odds ratio(OR) with confidence intervals of $95 \%$ ( $95 \% \mathrm{CI})$ were determined.

For the final multivariate model Greenland's recommendations were followed. Hosmer-Lemeshow Goodness of- fit- Test was calculated. For all the statistical tests probability values less than $5 \%$ were accepted as significant.

\section{Results}

The total of 406 students that were contacted agreed to participate. However, a student was excluded for filling out the questionnaire incorrectly. The group's ages ranged between 16 and 30 years, with a mean of 20.0 years $(\mathrm{SD}=2.2)$ divided in two categories; students under $20,246(60.7 \%)$ and over $20,159(39,2 \%)$. A total of $206(50.8 \%)$ students were women. Regarding the career, 121 (29.8\%) studied medicine; 99 (24.4\%) dentistry; 84 (20.7\%) nursing; $42(10.3 \%)$ chemistry and 59 (14.5\%) pharmaceutical chemistry, The group was divided into two subgroups: students studying chemistry or medicine and nursing, and students studying dentistry or pharmaceutical chemistry.

Students were grouped into two socioeconomic strata; low (1 to 3) 353 (87.2\%) students; and high (4 to 6) $52(12.8 \%)$ students; urban areas provenance 303 (74.8\%) students; living with their parents $250(61.7 \%)$ and others (family, friends, alone) 155 (38.3\%); 21 (5.2\%) students worked besides studying and 364 (89.8\%) participants were satisfied with their career. It was observed that 195 (48.1\%; 95\% CI 43.2 to 53.0) students had CSDS. Cronbach's alpha for Zung Self - Rating Depression Scale was 0.74 .

The bivariate analysis showed that students under 20 years had a higher prevalence of CSDS than those older than $20(52.4 \%$ vs. $41.5 \%$; OR $=1.6,95 \%$ CI 1.0 to 2,3$)$; women had a higher frequency than males $(52.9 \%$ vs. $43.2 ; \mathrm{OR}=1.5,95 \% \mathrm{CI} 1.0-2.2)$ and students studying nursing, dentistry and pharmaceutical chemistry showed a higher frequency of presenting CSDS than students in medicine and chemistry $54.5 \%$ vs. $39.7 \%$; OR $=1.9,95 \%$ CI 1.3 to 2.9 ). The final multivariate model is presented in "TABLE 1". This model adequately fit (Chi- square $=0.03$, degrees of freedom $=4, p=0.871$ ).

Table 1. Multivariate Model for CSDS in Students of the Health Area of a Public University in Cartagena, Colombia.

\begin{tabular}{|l|l|l|}
\hline CSDS & OR & CI95\% \\
\hline Career (nursing, dentistry and pharmaceutical chemistry) & 1,9 & $1,3-2,9$ \\
\hline Age (under 20 years) & 1,6 & $1,1-2,4$ \\
\hline
\end{tabular}

Source: Study Survey Results 


\section{Discussion And Conclusion}

The CSDS occur in about half of the students coursing health careers in Cartagena, Colombia. These symptoms are significantly associated with the studied career (nursing, dentistry and pharmaceutical chemistry) and age (under 20 years).

We observed in the present study that $48.1 \%$ of students in the health area reported CSDS. This data is similar to the $43.6 \%$ observed by Campo-Arias et al. instudents studying unrelated to health careers in a private university in Bucaramanga [8]. Guavita and Sanabria also found prevalences of $53.0 \%$ in medical students in a public university in Bogota [10]. However, Gaviria et al. documented a prevalence of 30.3\% among medical students of a private university in Medellin [17]. The prevalence of CSDS observed in the present study is remarkably high compared to Colombian adolescents in general, data reported by the national survey of mental health, of which about $80 \%$ of teens present 1 to 3 depressive symptoms and $16.6 \%$ of adult women and $15 \%$ of adult men report 4 to 6 depressivesymptoms [18].

Students under the age of 20, had an increased prevalence of CSDS in this research. This data is similar to what Guavita and Sanabria presented; They found a significantly higher prevalence of CSDS in ages between 18 and 20 years [10]. However, Shamssuddin et al. found that the prevalence of depression increased with age; students older than 20 years [3]. Whereas, Miranda et al.found no association between age and the presence of CSDS in medical students[11].

No association of CSDS in relation to gender was observed in this study. This finding is similar to that reported by Arrieta et al. in students of different careers [9]. However, Miranda et al. Aniebue et al. andAgudelo et al.reported a significant association between female gender and depressive symptoms in medical students $[4,11,25]$

Regarding the social stratum no significant association was observed, in the presented data. However, Arrieta et al. and Pereyra et al. found that low socioeconomic status was a risk factor for presenting CSDS[5,9].

No significant association between presenting CSDS and living with relatives was observed in the present study. The finding is similar to that observed by Guavita and Sanabria in medical students, who showed that living with family members present no association with CSDS [10]. However, Pereyra et al. showed that living away or with a family member external to the nuclear family increased the prevalence of depressive symptoms [5].

This study showed no significant association between the origin and the presence of CSDS.Similar information was documented by Amézquita et al. in undergraduates of several careers [7]. However, Shamsuddin et al. reported that depressive symptoms are more prevalent in students of rural areas [3].

A lack of relationship between working and studying at the same time and CSDS was evidenced in the present study; while association between studying nursing, dentistry or pharmaceutical chemistry and CSDS was observed. No studies that explored the association of these variables with CSDS were found.

Undoubtedly, CSDS frequency varies as the prevalence of depressive disorders. Depressive disorders are complex clinical entities related to multiple constitutional and environmental factors [19]. CSDS relate to academic stress and poor academic performance, suicidal ideation, suicide and university desertion $[5,6,7,9,21,22,23,24]$. It is therefore important to implement strategies aimed at early identification ofmood disorders in students.In addition, theearly identification of individuals at risk is of an extreme importance to both public health and the educational context to further explore the data obtained by the different studies, such as the nonconformity of the student with his/her academic performance, economy and living with an external family to his/her nuclear one, as associated factors that could be considered for developing prevention and intervention programs and appropriate student support services, which ultimately prevent desertion from academic life $[3,4,5,6,8,21,22,23,24,25]$.

The high prevalence of depression among university students studied here, requires the urgent need to implement preventive actions by the institution, in this contextthe University Welfare and faculty play an important role, to avoid behaviors that may jeopardize the lives and well being of young people. The nurse as a member of the health team, is able to assess factors prevailing psychosocial risk and direct educational activities, orientation to self-care, treatment, daily life activities and support groups, thus seeking the generation of a change in the attitude towards mental illness.

An important contribution of this study was to compare the prevalence of CSDS with careers, occupations and student's satisfaction in the health area, controlled by a multivariate model. However, this study was only conducted with students from a public university and no other variables that may be related to CSDS as family history, alcohol and substance abuse, among others were included [5,9].

It is concluded that about half of the students in the health careers of a public university in Cartagena, Colombia, reported CSDS. CSDS were associated with the participants careers and ages. Furthur studies that evaluate other associated factors specific to CSDSin the university context are needed. 


\section{References (in original language)}

[1]. American Psychiatric Association. Diagnostic and statistical manual of mental disorders. 5th edition. Washington, London: American Psychiatric Publishing; 2013.

[2]. Ibrahim A, Kelly S, Adams C, Glazebrook C. A systematic review of studies of depression prevalence in university students.Journal of Psychiatric Research. 2013; 47: 391-400.

[3]. Shamsuddin K, Fadzil F, Ismail W, Shah S, Khairani O, Muhammad N, Jaffar A, Ismail A, Mahadevan R. Correlates of depression, anxiety and stress among Malaysian university students. Asian Journal of Psychiatry. 2013; 6: 318-323.

[4]. Aniebue PN, Onyema GO. Prevalence of depressive symptoms among Nigerian medical undergraduates. Trop Doct. 2008; 38(3):157-8. doi:10.1258/td.2007.070202.

[5]. Pereyra R, Ocampo J, Silva V, Vélez E, Costa D, Toro LM, Vicuña J. Prevalencia y factores asociados con síntomas depresivos en estudiantes de ciencias de la salud de una universidad privada de Lima, Perú 2010.Rev Perú Med Exp Salud Publica. 2010; 27(4): 520-26.

[6]. Díaz Ramírez N. Depresión y Factores Asociados en Estudiantes de la Universidad Nacional de Colombia [Trabajo de grado para optar título de Magister en Psicología]. Departamento de Psicología Universidad Nacional de Colombia Enero de 2012

[7]. Amezquita E, González R, Zuluaga M. Prevalencia de la depresión, ansiedad y comportamiento suicida en la población estudiantil de pregrado de la universidad de Caldas. Rev Colomb Psiquiatr. 2000; 32: 341-56.

[8]. Campo A, Díaz L, Rueda G, Barros J. Validación de la escala de Zung para la depresión en universitarias de Bucaramanga, Colombia. Rev Colomb Psiquiatr. 2005; 34: 54-61.

[9]. Arrieta K, Díaz S, Gonzales F. Síntomas de depresión, ansiedad y estrés en estudiantes de odontología: prevalencia y factores relacionados. Rev. Colomb psiquiat. 2013; 42(2):173-181.

[10]. Guavita P, Sanabria P. Prevalencia de sintomatología depresiva en una población estudiantil de la Facultad de Medicina de la Universidad Militar Nueva Granada, Bogotá, Colombia. Rev. Fac Med. 2006; 54: 76-87.

[11]. Miranda C, Gutierrez J, Bernal F, Escobar C. Prevalencia de depresión en estudiantes de medicina de la Universidad del Valle. Rev Colomb Psiquiatr. 2000; 34: 251-9.

[12]. Olmedo B, Torres J, Velasco R, Mora A, Blas L. Prevalencia y severidad de depresión en estudiantes de enfermería de la Universidad de Colima. Rev Educ Invest Enferm 2006; 14 (1): 17-22.

[13]. Joffre V, Martínez G, García G, Sánchez L. Depresión en estudiantes de medicina resultado de la aplicación del inventario de depresión de Beck en su versión de 13 ítems. Rev Arg Clinic Neuro-psiquiatr. 2007; 14: 86-93.

[14]. Torres Y. Prevalencia de consumo de sustancias psicoactivas y factores asociados. Resultados de la investigación en jóvenes escolarizados del departamento de Antioquia 2003. Medellín: Editorial Marín Vieco Ltda; 2004.

[15]. Ministerio de Salud de Colombia. Resolución 008430 por la cual se establecen las normas científicas, técnicas y administrativas para la investigación en salud. Bogotá; 1993.

[16]. Díaz L, Campo A, Rueda G, Barros J. Propuesta de una versión abreviada de la escala de Zung para depresión.Colomb Med. 2005; 36: 168-72.

[17]. Gaviria S, Rodríguez M, Álvarez T. Calidad de la relación familiar y depresión en estudiantes de medicina de Medellín, Colombia 2000.Rev Chil Neuropsiquiatr 2002; 40: 41-6.

[18]. Restrepo C, Pacheco H .Encuesta Nacional de Salud Mental 2015.: Ministerio de Salud, Colciencias. Santafé de Bogotá 2015.

[19]. Goldberg D. Vulnerability factors for common mental illnesses. Br J Psychiatry 2001; 178: 69-71.

[20]. Tjia J, Givens J, Shea J. Factors associated with under treatment of medical student depression. J Am Coll Health 2005; $53: 219-24$.

[21]. Myers M. On the importance of anonymity in surveying medical students depression. Acad Psychiatry. 2003; 27: 19-20.

[22]. Gutiérrez JA, Montoya LP, Toro BE, Briñón MA, Restrepo ER, Salazar LE. Depresión en estudiantes universitarios y su asociación con el estrés académico, Revista Ces Medicina. 2010; 2(1):7-17

[23]. Polo A, Hernández J, Pozo C. Evaluación del estrés académico en estudiantes universitarios. [Último acceso en noviembre 13 de 2015]. Disponible en: http://www.unileon.es/estudiantes/atencion_universitario/articulo.

[24]. Micin S, Bagladi V. Salud Mental en Estudiantes Universitarios: Incidencia de Psicopatología y Antecedentes de Conducta Suicida en Población que Acude a un Servicio de Salud Estudiantil. Terapia Psicológica 2011; 29(1):53-64.

[25]. Agudelo DM, Casadiegos CP, Sánchez DL. Características de ansiedad y depresión en estudiantes universitarios. International Journal of Psychological Research. 2008; 1(1): 34 - 39. 